\title{
Correlation of human Bub1 expression with tumor-proliferating activity in salivary gland tumors
}

\author{
HIDEO SHIGEISHI $^{1}$, SHINGO YONEDA ${ }^{1}$, MASAYUKI TAKI ${ }^{1}$, TAKESHI NOBUMORI ${ }^{1}$, \\ KOUJI OHTA ${ }^{1}$, KOICHIRO HIGASHIKAWA ${ }^{1}$, WATARU YASUI ${ }^{2}$ and NOBUYUKI KAMATA ${ }^{1}$ \\ ${ }^{1}$ Division of Cervico-Gnathostomatology, Department of Oral and Maxillofacial Surgery; \\ ${ }^{2}$ Department of Molecular Pathology, Graduate School of Biomedical Sciences, \\ Hiroshima University, 1-2-3 Kasumi, Minami-ku, Hiroshima 734-8551, Japan
}

Received November 28, 2005; Accepted January 10, 2006

\begin{abstract}
Human Bub1 plays an important role at the spindle assembly check-point to prevent cell cycle progression following spindle damage. We examined the expression of Bubl mRNA and protein in 21 human salivary gland tumors (7 pleomorphic adenomas, 2 warthin tumors, 5 mucoepidermoid carcinomas, 3 adenoid cystic carcinomas and 4 acinic cell carcinomas) and 3 normal submandibular glands using real-time quantitative reverse transcription-polymerase chain reaction (RT-PCR) or Western blotting. The mean expression levels of Bubl mRNA and protein were higher in malignant tumors $(0.12 \pm 0.028 / 1.75 \pm 0.53)$ than normal submandibular glands $(0.042 \pm 0.014 / 0.19 \pm 0.044)$ and benign tumors $(0.058 \pm 0.01 / 0.97 \pm 0.44)$. We found a significant association between the level of Bubl mRNA/protein expression and clinical stage in malignant tumors (Mann-Whitney $\mathrm{U}$ test, $\mathrm{p}=0.019 / \mathrm{p}=0.016$ ). We analyzed its relation with the proliferative activity monitored by the Ki-67 labeling index by immunohistochemistry as well as the expression of proliferating cell nuclear antigen (PCNA) by Western blotting. A significant correlation was found between Bubl mRNA/ protein expression and the Ki-67 labeling index in salivary gland tumors (Spearman's correlation coefficient by rank test, $\mathrm{p}=0.026 / \mathrm{p}=0.002)$. These results indicate that increased expression of the human $B u b l$ gene is closely linked to abnormal cell proliferation in malignant conditions.
\end{abstract}

\section{Introduction}

The spindle assembly check-point ensures fidelity chromosome segregation by delaying anaphase until all chromosomes are correctly attached to the spindle and increases

Correspondence to: Dr Nobuyuki Kamata, Division of CervicoGnathostomatology, Department of Oral and Maxillofacial Surgery, Graduate School of Biomedical Sciences, Hiroshima University, 1-2-3 Kasumi, Minami-ku, Hiroshima 734-855, Japan

E-mail: nokam@hiroshima-u.ac.jp

Key words: Bub1, PCNA, Ki-67, salivary gland tumors the probability of successful delivery of an euploid chromosome set to each daughter cell (1-3). Genetic studies in Saccharomyces cerevisiae have identified seven genes (Bubl, Bub2, Bub3, Mad1, Mad2, Mad3 and Mps1) whose functions are required to properly arrest cell cycle progression following spindle damage $(4,5)$. Among them, Bubl encodes a protein kinase that localizes to the kinetochore and can phosphorylate Bub3 protein (6). In the presence of spindle damage, Bub1 is required to prevent cell cycle progression into anaphase (7). Loss of Bub1 function causes cells to prematurely exit from mitosis (7).

Genetic alteration analyses of the $B u b l$ gene have been reported to rarely occur in several human cancers (8-12). Overexpression of the Bubl gene has been reported in colorectal cancer (13). However, no study has been conducted to examine the expression of the Bubl gene in human salivary gland tumors.

In this study, we examined the expression of human Bub1, PCNA and Ki-67 in salivary gland tumors to clarify the correlation between Bub1 expression and cell proliferating activity.

\section{Materials and methods}

Tissue samples. We examined 21 salivary gland tumors; seven pleomorphic adenomas, two warthin tumors, five mucoepidermoid carcinomas, three adenoid cystic carcinomas, and four acinic cell carcinomas (Tables I and II). Tumors were classified according to the criteria of the Armed Forces Institute of Pathology's classification of salivary gland tumors (14). Salivary gland tumor tissue and specimens of normal salivary glands were obtained with informed consent and approval from the institutional review board at Hiroshima University Dental Hospital (Japan). For molecular analyses, tissue samples obtained at the time of surgery were frozen immediately in liquid nitrogen and stored at $-80^{\circ} \mathrm{C}$. We confirmed microscopically that the tumor specimens consisted mainly of carcinoma tissue and that the specimens of normal submandibular glands did not exhibit any tumor cell invasion or show significant inflammatory involvement.

RNA extraction and quantitative RT-PCR analysis. RNA was extracted using an RNAeasy Mini Kit (Qiagen, Hilden, 
Table I. Expression of Bubl in normal submandibular glands and benign salivary gland tumors.

\begin{tabular}{|c|c|c|c|c|}
\hline \multirow[b]{2}{*}{ Case no. } & \multirow[b]{2}{*}{ Location $^{\mathrm{a}}$} & \multicolumn{2}{|c|}{ Bub1 expression levels } & \multirow[b]{2}{*}{$\mathrm{PCNA}^{\mathrm{d}}$} \\
\hline & & $\mathrm{mRNA}^{\mathrm{b}}$ & Protein $^{c}$ & \\
\hline \multirow{2}{*}{\multicolumn{5}{|c|}{$\begin{array}{l}\text { Normal } \\
\text { submandibular } \\
\text { gland }\end{array}$}} \\
\hline & & & & \\
\hline 1 & & 0.024 & 0.19 & 0.053 \\
\hline 2 & & 0.071 & 0.26 & ND \\
\hline 3 & & 0.031 & 0.11 & ND \\
\hline \multirow{2}{*}{\multicolumn{5}{|c|}{$\begin{array}{l}\text { Pleomorphic } \\
\text { adenoma }\end{array}$}} \\
\hline & & & & \\
\hline 4 & Palate & 0.054 & 0.087 & 0.084 \\
\hline 5 & SMG & 0.084 & ND & ND \\
\hline 6 & SMG & 0.037 & ND & ND \\
\hline 7 & PG & 0.054 & ND & ND \\
\hline 8 & Palate & 0.04 & 0.55 & 0.21 \\
\hline 9 & Palate & 0.025 & 0.87 & 0.30 \\
\hline 10 & PG & 0.067 & 0.25 & 0.12 \\
\hline \multicolumn{5}{|l|}{$\begin{array}{l}\text { Warthin } \\
\text { tumor }\end{array}$} \\
\hline 11 & PG & 0.037 & ND & ND \\
\hline 12 & PG & 0.12 & 3.03 & 3.63 \\
\hline
\end{tabular}

aLocation: SMG, submandibular gland; PG, palotid gland. ${ }^{\mathrm{b}} \mathrm{mRNA}$, level of mRNA expression was normalized with respect to internal control ( $\beta$-actin). ${ }^{c}$ Protein, level of protein expression was normalized with respect to internal control ( $\alpha$-tubulin). ${ }^{\mathrm{d}} \mathrm{PCNA}$, level of PCNA protein expression was normalized with respect to internal control ( $\alpha$-tubulin). ND, not determined.

Germany). Total RNA (1 $\mu \mathrm{g})$ was subjected to a reversetranscriptase reaction using the First Strand cDNA Synthesis kit (Amersham Biosciences, Uppsala, Sweden). The quantification of mRNA levels was carried out using a realtime fluorescence detection method according to the method of Eads et al (15). The fluorescence was detected by the laser detector of the ABI PRISM 7700 Sequence Detection System (Perkin-Elmer, Foster city, CA) and the detection was carried out by measuring the binding of a fluorescence dye, SYBRGreen I, to double-stranded DNA. The PCR was run in microtubes in a volume of $25 \mu 1$. The reaction mixture contained $1.0 \mu \mathrm{g}$ of cDNA, $10 \mu \mathrm{l}$ of SYBR-Green PCR Master Mix (Applied Biosystems), and 10 pmol of each pair of oligonucleotide primers. The primer sequences were: Bub1, 5'-TCATTCATGGAGACATTAAAC-3' (sense), 5'CTGAGCATCTCAACACACTG-3' (antisense); and B-actin, 5'-TGAGCGCGGCTACAGCTT-3' (sense), 5'-CCTTAAT GTCACACACGATT-3' (antisense). The PCR program was as follows: initial melting at $95^{\circ} \mathrm{C}$ for $10 \mathrm{~min}$ followed by 40 cycles at $95^{\circ} \mathrm{C}$ for $15 \mathrm{sec}$ and $60^{\circ} \mathrm{C}$ for $60 \mathrm{sec}$. The quantification of Bub1 mRNA relative to an internal control, $\beta$-actin, was performed by the $\Delta \mathrm{C}_{\mathrm{t}}$ method according to Tanaka et al (16). Results of the quantitative RT-PCR analysis of one salivary gland tumor sample are shown in Fig. 1.

Protein extraction and Western blotting. Protein extraction was carried out as described (17). The protein concentration was determined by the Bradford dye-binding protein assay (Bio-Rad, Richmond, CA) using bovine serum albumin (Sigma Chemical Co., St. Louis, MO ) as a standard. Protein samples $(30 \mu \mathrm{g})$ were solubilized in sample buffer by boiling and subjected to sodium dodecyl sulfate-poly-acrylamide gel electrophoresis (SDS-PAGE) followed by electrotransfer onto a nitrocellulose filter (Schleicher \& Schuell, Dasse, Germany). Anti-human Bub1 monoclonal antibody (Chemicon, USA) and anti-human PCNA monoclonal antibody (MBL, Tokyo, Japan) were used in this study. The immune complex was detected using the ECL Western-blotting detection system (Amersham, Aylesbury, UK). Anti- $\alpha$-tubulin mouse monoclonal antibody (Zymed Laboratories, South San Francisco, CA) was used as a positive control of Western blotting. Densitometric scanning was performed on signals normalized by the internal control ( $\alpha$-tubulin).

Immunohistochemistry. Avidin-biotin-peroxidase complex immunostaining was performed as described previously (18). For the Ki-67 labeling index, immunohistochemical analysis was performed using an anti-Ki-67 monoclonal antibody (Dako, Copenhagen, Denmark). The proportion of tumor cell nuclei stained by Ki-67 was calculated for each tumor in x200 microscopic fields. All tumor cell nuclei stained brown above the background level, regardless of intensity, were considered positively stained. We presented the Ki-67 positive cell ratio as the number of tumor cells immunostained by Ki-67 per 1000 carcinoma cells in each case (Ki-67 labeling index). The Ki-67 labeling index was classified as low $(<5 \%)$ or high $(\geq 5 \%)$.

Statistical methods. The Mann-Whitney U test and Spearman's correlation coefficient by rank test were used for statistical analysis. P-values of $<0.05$ were regarded as statistically significant.

\section{Results}

Expression of Bubl mRNA in salivary gland tumors. We examined the expression of Bubl mRNA in 21 salivary gland tumors and 3 normal submandibular glands by real-time RT-PCR. The overall results are summarized in Tables I and II. The mean expression level of Bub1 mRNA was higher in malignant tumors $(0.12 \pm 0.028)$ than normal submandibular glands $(0.042 \pm 0.014)$ and benign tumors $(0.058 \pm 0.01)$ as shown in Fig. 2. Malignant tumors showed high levels of Bub1 mRNA expression compared to benign tumors, although the difference was not significant (Mann-Whitney U test, $\mathrm{p}=0.27$ ). The expression of Bubl mRNA did not correlate with clinicopathological factors such as age, gender, tumor type and tumor location. Data on Bubl mRNA expression, tumor size, clinical stage and lymph node metastasis are summarized in Table III. A significant association was found 
Table II. Expression of Bubl mRNA in malignant salivary gland tumors.

\begin{tabular}{|c|c|c|c|c|c|c|}
\hline \multirow[b]{2}{*}{ Case no. } & \multirow[b]{2}{*}{ Location $^{\mathrm{a}}$} & \multirow[b]{2}{*}{ Stage $^{b}$} & \multirow[b]{2}{*}{ Meta $^{c}$} & \multicolumn{2}{|c|}{ Bub1 expression levels } & \multirow[b]{2}{*}{ PCNA $^{f}$} \\
\hline & & & & $\mathrm{mRNA}^{\mathrm{d}}$ & Protein ${ }^{\mathrm{e}}$ & \\
\hline \multicolumn{7}{|c|}{ Mucoepidermoid carcinoma } \\
\hline 13 & Mandibule & IV & - & 0.22 & 4.96 & 1.95 \\
\hline 14 & PG & IV & + & 0.12 & 4.19 & 1.95 \\
\hline 15 & Oral floor & II & - & 0.053 & 0.72 & 1.09 \\
\hline 16 & Maxilla & IV & + & 0.14 & 1.79 & 1.66 \\
\hline 17 & Mandibule & IV & + & 0.08 & ND & ND \\
\hline \multicolumn{7}{|c|}{ Acinic cell carcinoma } \\
\hline 18 & Maxilla & II & - & 0.023 & 0.63 & 0.16 \\
\hline 19 & PG & I & - & 0.067 & 0.64 & 0.33 \\
\hline 20 & PG & III & + & 0.049 & 0.69 & 0.42 \\
\hline \multicolumn{7}{|c|}{ Adenoid cystic carcinoma } \\
\hline 21 & Oral floor & III & + & 0.30 & 2.94 & 1.06 \\
\hline 22 & Oral floor & II & - & 0.061 & 0.36 & 0.47 \\
\hline 23 & Oral floor & I & - & 0.048 & 0.60 & 0.97 \\
\hline 24 & Buccal mucosa & IV & - & 0.29 & ND & ND \\
\hline
\end{tabular}

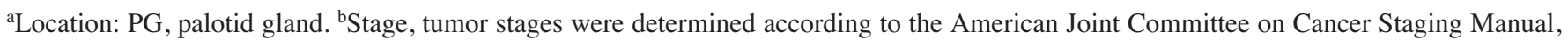
5th edition. ${ }^{\mathrm{c} M e t a:}+$, presence of lymph node metastasis; -, negative lymph node metastasis. ${ }^{\mathrm{d}} \mathrm{mRNA}$, level of mRNA expression was

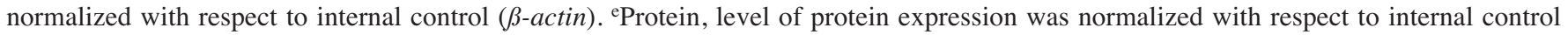

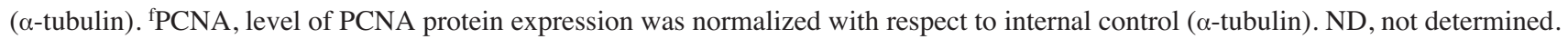

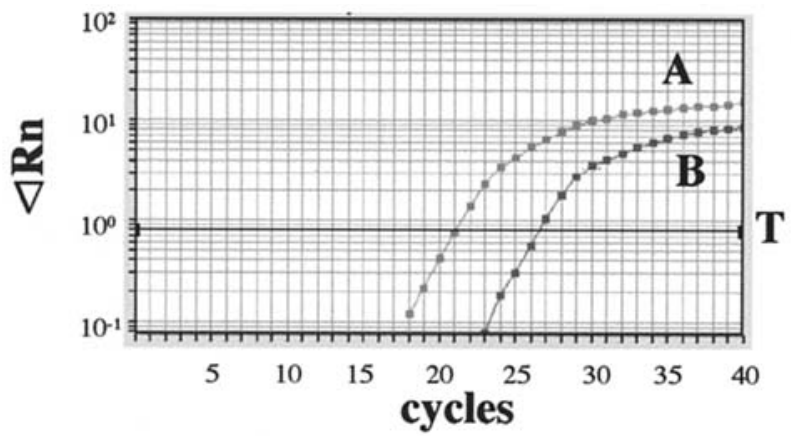

Figure 1. Amplification curves of real-time quantitative PCR analysis of 1 salivary gland tumor sample: A, $B$-actin; B, Bub1; T, threshold; $\Delta$ Rn, fluorescence of SYBR-Green I dye.

between the level of Bubl mRNA expression and clinical stage (Mann-Whitney U test, $\mathrm{p}=0.019$ ). Patients with larger tumors showed higher levels of Bubl mRNA expression and those with lymph node metastasis showed higher levels of Bubl mRNA expression than the patients without metastasis, although a significant association was not found in either case.

Expression of Bubl and PCNA protein in salivary gland tumors. We further analyzed the protein expression of Bub1 and its relation with the proliferative activity monitored by the expression of proliferating cell nuclear antigen (PCNA)

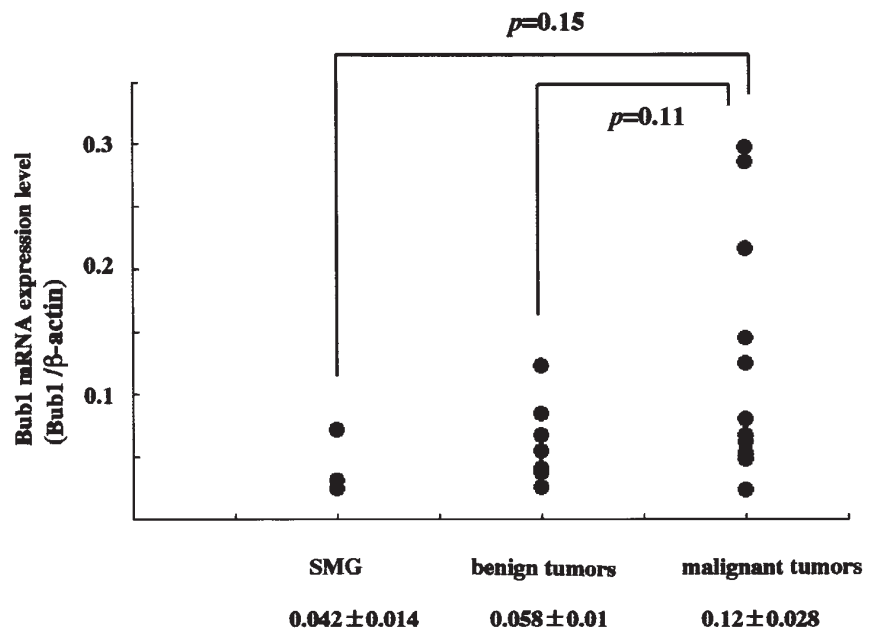

Figure 2. Levels of Bubl mRNA expression in normal submandibular glands, benign salivary gland tumors and malignant salivary gland tumors: each point represents the Bubl mRNA expression level.

on Western blotting (Fig. 3). We performed densitometric scanning and normalized the signal intensities to an internal control ( $\alpha$-tubulin expression). The overall results are summarized in Tables I and II. We found a significant association between expression levels of Bubl mRNA and protein in 3 submandibular glands and 15 salivary gland tumors (Mann-Whitney U test, $\mathrm{p}=0.023$ ). The mean expression 
Table III. Expression of Bubl mRNA in salivary gland carcinomas and its correlation with clinicopathological parameters.

Expression level of $B u b 1$

Case no. $\quad \overline{\text { Mean } \pm \text { SD } \quad \text { P-value }^{b}}$

Tumor size ${ }^{\mathrm{a}}$

$\mathrm{T} 1$

$\mathrm{T} 2$

$\mathrm{T} 4$

$$
\begin{array}{r}
0.057 \pm 0.01 \\
0.097 \pm 0.05 \\
0.17 \pm 0.36
\end{array}
$$

0.12

5

$5 \quad 0.17 \pm 0.36$

Clinical stage $\mathrm{e}^{\mathrm{a}}$

$\begin{array}{llr}\text { I + II } & 5 & 0.054 \pm 0.007 \\ \text { III + IV } & 7 & 0.17 \pm 0.037\end{array}$

0.019

Lymph node

metastasis

\begin{tabular}{lll} 
Positive & 5 & $1.55 \pm 0.042$ \\
Negative & 7 & $0.11 \pm 0.038$ \\
\hline
\end{tabular}

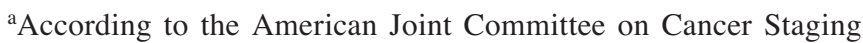

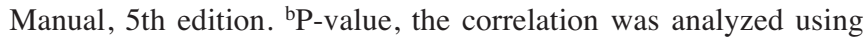
the Mann-Whitney U test and p-values are shown. P-values $<0.05$ were regarded as statistically significant.

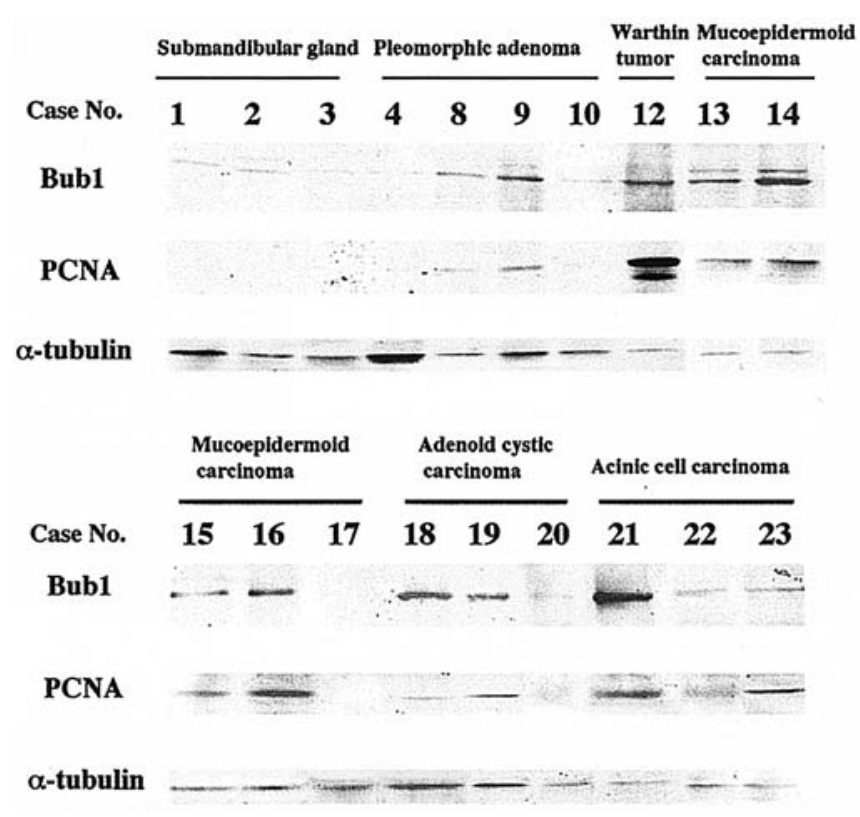

Figure 3. The expression of Bub1 and PCNA protein in normal submandibular glands and salivary gland tumors. The expression of $\alpha$-tubulin was used as a positive control of Western blotting.

level of Bub1 protein was higher in malignant tumors $(1.75 \pm 0.53)$ than normal submandibular glands $(0.19 \pm 0.044)$ and benign tumors $(0.97 \pm 0.44)$. Data on Bub1 protein expression, tumor size, clinical stage and lymph node metastasis are summarized in Table IV. A significant
Table IV. Expression of Bub1 protein in salivary gland carcinomas and its correlation with clinicopathological parameters.

Expression level of Bub1

Case no. $\quad$ Mean \pm SD $\quad$ P-value $^{\mathrm{b}}$

Tumor size ${ }^{\mathrm{a}}$

$\begin{array}{lll}\mathrm{T} 1 & 2 & 0.62 \pm 0.018 \\ \mathrm{~T} 2 & 5 & 1.07 \pm 0.47 \\ \mathrm{~T} 4 & 3 & 3.65 \pm 0.95\end{array}$

Clinical stage

$\begin{array}{lll}\text { I + II } & 5 & 0.59 \pm 0.06 \\ \text { III + IV } & 5 & 2.91 \pm 0.78\end{array}$

Lymph node metastasis

\begin{tabular}{lll} 
Positive & 4 & $2.41 \pm 0.75$ \\
Negative & 6 & $1.32 \pm 0.73$ \\
\hline
\end{tabular}

aAccording to the American Joint Committee on Cancer Staging

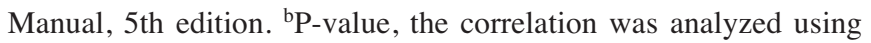
the Mann-Whitney U test and $\mathrm{p}$ values are shown. P-values $<0.05$ were regarded as statistically significant.

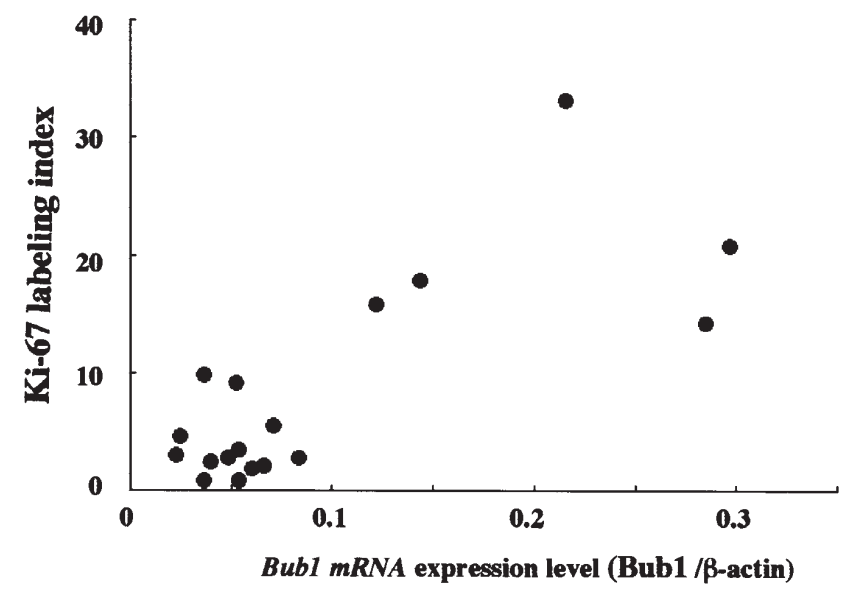

Figure 4. Correlation between the Ki-67 labeling index and Bub1 mRNA expression in salivary gland tumors. A significant correlation was found between the Ki-67 labeling index and Bubl (Spearman's correlation coefficient by rank test, $\mathrm{p}=0.026$ ).

association was found between the level of Bub1 protein expression and clinical stage (Mann-Whitney U test, $\mathrm{p}=0.016$ ). The expression levels of Bub1 protein correlated well with the levels of PCNA protein in one submandibular gland and 15 salivary gland tumors (Mann-Whitney U test, $\mathrm{p}=0.001$ ).

Immunohistochemistry for Ki-67 in salivary gland tumors. We further examined the expression of Ki-67 in salivary 


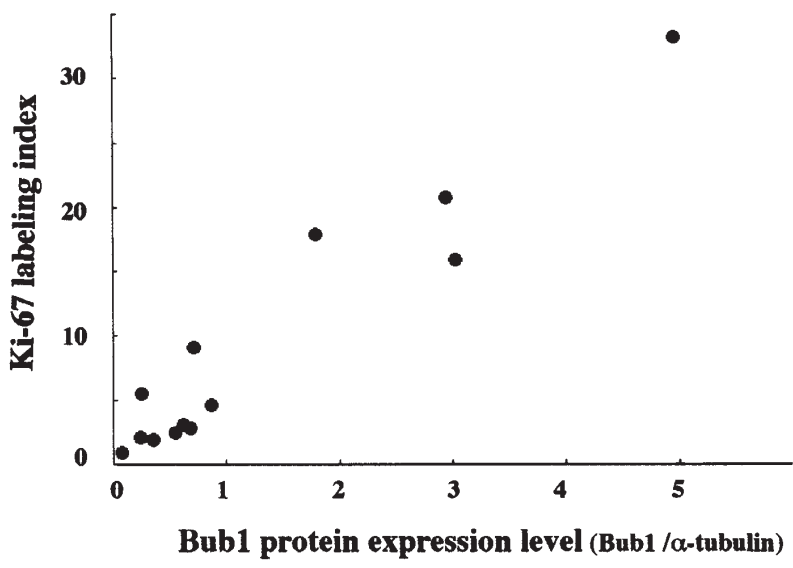

Figure 5. Correlation between the Ki-67 labeling index and Bub1 protein expression in salivary gland tumors. A significant correlation was found between the Ki-67 labeling index and Bub1 protein (Spearman's correlation coefficient by rank test, $\mathrm{p}=0.002$ ).

gland tumors immunohistochemically to investigate the correlation between Bub1 expression and proliferating activity. The mean level of Ki-67 labeling index was higher in malignant tumors $(12.8 \pm 3.86)$ than benign tumors $(4.68 \pm 1.67)$. The index was compared with the expression levels of Bub1 in the tumors. The average Bubl mRNA expression in the cases with a high $\mathrm{Ki}-67$ labeling index $(\geq 5 \%)$ and with a low labeling index $(<5 \%)$ was $0.16 \pm 0.04$ and $0.049 \pm 0.006$, respectively, indicating a significant correlation between the Ki-67 labeling index and Bub1 expression in salivary gland tumors (Spearman's correlation coefficient by rank test, $\mathrm{p}=0.026$ ) (Fig. 4). We also found a significant correlation between the expression levels of Bub1 protein and Ki-67 labeling index (Spearman's correlation coefficient by rank test, $\mathrm{p}=0.002$ ) (Fig. 5). These findings suggest that expression of the human Bub1 gene is closely associated with tumor proliferating activity.

\section{Discussion}

Chromosome segregation in mitosis depends on kinetochores, complex protein structures that assemble at the centromeres of chromosomes (19). The spindle assembly check-point ensures accurate segregation of chromosomes (1-3). The check-point is mediated by a signal transduction system comprised of Mad and Bub proteins $(2,20)$. The human $B u b l$ gene is a protein kinase which localizes to kinetochores very early in prophase and plays a surveillance role in preventing the missegregation of chromosomes $(20,21)$. A significant number of paired sister chromatids fail to move to the metaphase plate and kinetochores on these chromatids appear to bind in Bub1 depleted human cells (22). These observations suggest that human Bub1 is essential for check-point control and for correct chromosome congression. Bub1 is also required for efficient kinetochore localization of BubR1 and Mad2 in human somatic cells (23). Bub1 plays a key role in the assembly of check-point proteins at the kinetochore.

Mutant forms of the Bubl gene were identified in colorectal cancer cell lines with chromosomal instability (24). However, mutational inactivation of the $B u b l$ gene is a very rare event and plays a very restricted role in human cancers including carcinomas of the digestive tract, breast and lung (8-11). We have also performed sequencing analysis of the human Bubl gene in several cases of gastric carcinoma and could not identify any mutations (12). These observations indicate that mutational inactivation of the $B u b l$ gene rarely occurs in human cancers.

Ouyang et al reported that the human Bubl mRNA level was abundantly expressed in primary human tissue and cancer cells with a high mitotic index (7). We have reported that the expression levels of Bubl mRNA correlated with the levels of PCNA protein and Ki-67 labeling index in several human gastric carcinoma cases (25). Grabsch et al also reported that there was a statistically significant positive correlation between overexpression of Bub1, BubR1 or Bub3 and Ki-67 expression (26). These observations suggest that human Bubl mRNA is closely linked to cell proliferation in human gastric carcinomas. However, it is not known whether Bub1 expression levels reflect spindle check-point function in human cancers. Further investigations are required to establish whether there is an association between Bub1 expression levels and check-point function.

Salivary gland tumors are uncommon with a broad heterogeneity $(27,28)$. The most common benign tumor is the pleomorphic adenoma, whereas mucoepidermoid carcinoma, adenoid cystic carcinoma and acinic cell carcinoma predominate among malignant tumors. In this study, we found that expression levels of Bubl mRNA and protein were higher in malignant salivary gland tumors than in benign salivary gland tumors and normal submandibular gland tissue. A significant association between expression levels of $\mathrm{Bubl}$ mRNA/protein and clinical stage was found in malignant salivary tumors. The results indicate that the $B u b l$ gene is associated with tumor progression in malignant salivary gland tumors. Furthermore, we demonstrated a significant association between the expression level of Bubl mRNA/protein and the Ki-67 labeling index, which has been reported to correlate with the prognosis of various salivary gland carcinomas $(29,30)$. PCNA, an auxiliary protein for DNA polymerase $\delta$, plays an important role in DNA synthesis and is thought to be localized to nuclei, particularly during late $\mathrm{G}$ and $\mathrm{S}$ phases $(31,32)$. The expression of PCNA is a useful marker in evaluating the cell proliferating activity in human salivary gland tumors $(33,34)$. In this study, Bub1 protein expression correlated with PCNA expression using Western blot analysis. We have also analyzed the expression levels of BubRl and $B u b 3$ mRNA in salivary gland tumors. The expression levels of BubR1 and Bub3 mRNA were higher in malignant salivary gland tumors than benign salivary gland tumors and normal submandibular gland tissue (Shigeishi et al, unpublished data). However, we could not find a significant association between the expression levels of BubR1/Bub3 mRNA and the Ki-67 labeling index (Shigeishi et al, unpublished data). These results indicate that expression of the human $B u b l$ gene is strongly associated with tumor-proliferating activity in human salivary gland carcinomas.

Bub1 is required for kinetochore localization of centromere protein-F (CENP-F) in human somatic cells (23). CENP-F is a kinetochore protein identified through the use of human autoimmune sera (35). CENP-F plays several important roles 
in mitotic events, including centromere/kinetochore maturation, chromosome alignment and segregation, and anaphase spindle stabilization (36). We have already reported that human $C E N P-F$ mRNA is closely linked to the increased or abnormal cell proliferation in salivary gland carcinomas (37). The increased expression of Bub1 and CENP-F gene might cause cell cycle progression and high proliferative activity in malignant conditions.

Since the numbers of cases of each salivary gland carcinoma investigated in this study were relatively small, further analysis is needed to confirm the correlation between Bub1 expression and tumor-proliferating activity. The present study suggests the usefulness of the $B u b l$ gene as an additional diagnostic tool for salivary gland carcinomas.

\section{Acknowledgements}

This study was supported by a Grant-in-aid from the Japanese Ministry of Education, Culture, Sports and Technology.

\section{References}

1. Rudner AD and Murray AW: The spindle assembly checkpoint. Curr Opin Cell Biol 8: 773-780, 1996.

2. Hoyt MA, Totis L and Roberts BT: S. cerevisiae genes required for cell cycle arrest in response to loss of microtubule function. Cell 66: 507-517, 1991.

3. Pennisi E: Cell division gatekeepers identified. Science 279: 477-478, 1998.

4. Roberts BT, Farr KA and Hoyt MA: The Saccharomyces cerevisiae cerevisiae spindle assembly checkpoint. Mol Cell Biol 14: 8282-8291, 1994.

5. Farr KA and Hoyt MA: Bublp kinase activates the Saccharomyces subjected to cytoplasmic dynein-mediated poleward transport. Mol Cell Biol 18: 2738-2747, 1998.

6. Roberts BT, Farr KA and Hoyt MA: The Saccharomyces cerevisiae checkpoint gene BUB1 encodes a novel protein kinase. Cell Growth Differ 9: 877-885, 1998

7. Ouyang B, Lan Z, Meadows J, Pan H, Fukasawa K, Li W and Dai W: Human Bub1: a putative spindle checkpoint kinase closely linked to cell proliferation. Curr Opin Cell Biol 8: 773-780, 1996.

8. Imai Y, Shiratori Y, Kato N, Inoue T and Omata M: Mutational inactivation of mitotic checkpoint genes, hsMAD2 and hBUB1, is rare in sporadic digestive tract cancers. Jpn J Cancer Res 90: 837-840, 1999.

9. Myrie KA, Percy MJ, Azim JN, Neeley CK and Petty EM: Mutation and expression analysis of human BUB1 and BUB1B in aneuploid breast cancer cell lines. Cancer Lett 152: 193-199, 2000.

10. Yamaguchi K, Okami K, Hibi K, Wehage SL, Jen J and Sidransky D: Mutation analysis of hBUB1 in aneuploid HNSCC and lung cancer cell lines. Cancer Lett 139: 183-187, 1999.

11. Langerod A, Stromberg M, Chin K, Kristensen VN and Borresen-Dale AL: BUB1 infrequently mutated in human breast carcinomas. Hum Mutat 22: 420, 2003.

12. Shigeishi H, Yokozaki H, Kuniyasu H, Nakagawa H, Ishikawa T, Tahara $\mathrm{E}$ and Yasui W: No mutations of the Bub1 gene in human gastric carcinomas. Oncol Rep 8: 791-794, 2001.

13. Shichiri M, Yoshinaga K, Hisatomi H, Sugihara K and Hirata Y: Genetic and epigenetic inactivation of mitotic checkpoint genes hBUB1 and hBUBR1 and their relationship to survival. Cancer Res 62: 13-17, 2002.

14. Ellis GL and Auclair PL: Tumors of the salivary glands. In: Atlas of Tumor Pathology. Rosai J and Sobin LH (eds). Armed Forces Institute of Pathology, Washington, DC, 1995.

15. Eads CA, Danenberg KD, Kawakami K, Saltz LB, Danenberg PV and Laird PW: CpG island hypermethylation in human colorectal tumors is not associated with DNA methyltransferase overexpression. Cancer Res 59: 2302-2306, 1999.
16. Tanaka S, Kobayashi I, Utsuki S, Oka H, Fujii K and Watanabe T: O6-methylguanine-DNA methyltranspherase gene expression in gliomas by means of real-time quantitative RT-PCR and clinical response to nitrosoureas. Int J Cancer 103: 67-72, 2003.

17. Yasui W, Kuniyasu H, Yokozaki H, Semba S, Shimamoto F and Tahara E: Expression of cycline E in colorectal adenomas and adenocarcinomas: correlation of Ki67 and p53 protein. Virchows Arch 429: 13-19, 1996.

18. Kuniyasu H, Oue N, Shigeishi H, Ito R, Kato Y, Yokozaki H and Yasui W: Prospective study of Ki-67 labeling index in the mucosa adjacent to cancer as a marker for colorectal cancer metastasis. J Exp Clin Cancer Res 20: 543-548, 2001.

19. Amon A: The spindle checkpoint. Curr Opin Genet Dev 9: 69-75, 1999.

20. Lengauer $\mathrm{C}$ and Wang Z: From spindle checkpoint to cancer. Nat Genet 36: 1144-1145, 2004.

21. Jablonski SA, Chan GK, Cooke CA, Earnshaw WC and Yen TJ: The hBUB1 and hBUBR1 kinases sequentially assemble onto kinetochores during prophase with hBUBR1 concentrating at the kinetochore plates in mitosis. Chromosoma 107: 386-396, 1998.

22. Meraldi P and Sorger PK: A dual role for Bub1 in the spindle checkpoint and chromosome congression. EMBO J 24: 1621-1633, 2005.

23. Johnson VL, Scott MI, Holt SV, Hussein D and Taylor SS: Bub1 is required for kinetochore localization of BubR1, Cenp-E, Cenp-F and Mad2, and chromosome congression. J Cell Sci 117: 1577-1589, 2004.

24. Cahill DP, Lengauer C, Yu J, Riggins GJ, Willson JK, Markowitz SD, Kinzler KW and Vogelstein B: Mutations of mitotic checkpoint genes in human cancers. Nature 392: 300-303, 1998.

25. Shigeishi H, Oue N, Kuniyasu H, Wakikawa A, Yokozaki H, Ishikawa $\mathrm{T}$ and Yasui W: Expression of Bub1 gene correlates with tumor proliferating activity in human gastric carcinomas. Pathobiology 69: 24-29, 2001.

26. Grabsch H, Takeno S, Parsons WJ, Pomjanski N, Boecking A, Gabbert HE and Mueller W: Overexpression of the mitotic checkpoint genes BUB1, BUBR1 and BUB3 in gastric cancerassociation with tumour cell proliferation. J Pathol 200: 16-22, 2003.

27. Eveson JW and Cawson RA: Salivary gland tumours. A review of 2410 cases with particular reference to histological types, site, age and sex distribution. J Pathol 146: 51-58, 1985.

28. Spiro RH: Salivary neoplasms: overview of a 35-year experience with 2,807 patients. Head Neck Surg 8: 177-184, 1986.

29. Hellquist HB, Sundelin K, Di Bacco A, Tytor M, Manzotti M and Viale G: Tumour growth fraction and apoptosis in salivary gland acinic cell carcinomas. Prognostic implications of Ki-67 and bcl-2 expression and of in situ end labelling (TUNEL). J Pathol 181: 323-329, 1997.

30. Nordgard S, Franzen G, Boysen M and Halvorsen TB: Ki-67 as a prognostic marker in adenoid cystic carcinoma assessed with the monoclonal antibody MIB1 in paraffin sections. Laryngoscope 107: 531-536, 1997.

31. Garcia RL, Coltrera MD and Grown AM: Analysis of proliferative grade using anti PCNA/cyclin in fixed, embedded tissues. Am J Pathol 134: 733-739, 1989.

32. Landberg G, Tan EM and Roos G: Flow cytometric multiparameter analysis of proliferating cell nuclear antigen/cyclin and Ki-67 antigen. Exp Cell Res 187: 111-118, 1990.

33. Skalova A and Leivo I: Cell proliferation in salivary gland tumors. Gen Diagn Pathol 142: 7-16, 1996.

34. Russo G, Zamparelli A, Howard CM, Minimo C, Bellan C, Carillo G, Califano L, Leoncini L, Giordano A and Claudio PP: Expression of cell cycle-regulated proteins pRB2/p130, p107, $\mathrm{E} 2 \mathrm{~F} 4, \mathrm{p} 27$ and pCNA in salivary gland tumors: prognostic and diagnostic implications. Clin Cancer Res 11: 3265-3273, 2005.

35. Rattner JB, Rao A, Fritzler MJ, Valencia DW and Yen TJ: CENP-F is a .ca $400 \mathrm{kDa}$ kinetochore protein that exhibits a cell-cycle dependent localization. Cell Motil Cytoskeleton 26: 214-226, 1993.

36. Yang ZY, Guo J, Li N, Qian M, Wang SN and Zhu XL: Mitosin/CENP-F is a conserved kinetochore protein subjected to cytoplasmic dynein-mediated poleward transport. Cell Res 13: 275-283, 2003.

37. Shigeishi H, Mizuta K, Higashikawa K, Yoneda S, Ono S and Kamata N: Correlation of CENP-F gene expression with tumorproliferating activity in human salivary gland tumors. Oral Oncol 41: 716-722, 2005. 